\title{
Optimal Interpolation and Ecological Risk Assessment of Spatial Distribution of Heavy Metals in Soil Based on GIS and Geostatistics - A Case Study of Low-lying Land of the Lower Yellow River, China
}

\author{
Yanyan Li ${ }^{1}$, Dan Yang ${ }^{1}$, Pengyan Zhang1,2*, Wenliang Geng ${ }^{1}$, Ying Liu ${ }^{1}$, \\ Hao Chang ${ }^{1}$, Mingzhou Qin ${ }^{1,2 * *}$, Tianqi Rong ${ }^{1}$, Jingwen Shao ${ }^{1}$
}

\begin{abstract}
${ }^{1}$ Key Laboratory of Geospatial Technology for Middle and Lower Yellow River Region, Research Center of Regional Development and Planning, Institute of Agriculture and Rural Sustainable Development, Henan Overseas Expertise Introduction Center for Discipline Innovation (Ecological Protection and Rural Revitalization along the Yellow River), Henan University, Kaifeng, China

${ }^{2}$ Collaborative Innovation Center on Yellow River Civilization of Henan Province, Henan University, Kaifeng, China
\end{abstract}

Received: 25 July 2020

Accepted: 4 November 2020

\begin{abstract}
Soil environmental quality plays an important role in ensuring human health and food security. Therefore, increasingly attention has been paid to the ecological and environmental problems affecting river basins worldwide. The Yellow River is the second longest river in China and the fifth longest river in the world, thus it has great significance globally and locally. In recent years, the ecological protection and exploitation of the Yellow River Basin have attracted much attention, especially regarding changes in vegetation, water, and sediment, as well as soil quality problems. This research concentrates on the assessment of soil heavy metals in the low-lying land, a typical landform unique to the Yellow River Basin, which is of great significance for the study of food security, cultivated land protection, and cultivated land resources in developing countries. Here, 156 surface soil $(0-20 \mathrm{~cm})$ samples, and eight elements ( $\mathrm{Cd}, \mathrm{Cr}, \mathrm{Ni}, \mathrm{Pb}, \mathrm{Cu}, \mathrm{Zn}, \mathrm{As}$, and $\mathrm{Hg}$ ) were collected to be measured and studied. We found that only the average value of $\mathrm{Cd}$ exceeded the standard. By comparing the above six interpolation methods, the optimal interpolation model was selected for the analysis of the spatial distribution characteristics of the heavy metal content in eight soils in the study area. Regarding the spatial distribution, we observed that higher concentrations in the west, with lower concentrations in the east; all heavy metals exhibited high-value zones. The evaluation of the potential ecological risk index revealed that only $\mathrm{Cd}$ reached the moderate level. $\mathrm{Zn}, \mathrm{Pb}, \mathrm{Cd}$, and $\mathrm{Hg}$ were greatly affected by anthropogenic sources, and $\mathrm{Cu}, \mathrm{Cr}$,
\end{abstract}

*e-mail: pengyanzh@126.com

**e-mail: mzqin@henu.edu.cn 
$\mathrm{Ni}$, and As were greatly affected by natural sources. Therefore, $\mathrm{Cd}$ was found to be the main risk factor in the region and $\mathrm{Cd}$ soil levels should thus be closely monitored in the study area.

Keywords: heavy metals, interpolation method, spatial analysis, pollution assessment, low-lying land

\section{Introduction}

Soil is an important natural resource and an important part of human development and the ecological environment [1-3]. Urbanization continues to accelerate with socioeconomic development, consequently, the soil environment is also facing serious threats [4-5]. In the past 50 years, a good deal of heavy metals had been discharged into the global environment. Notably, most of these heavy metals have entered the soil, causing soil heavy metal pollution [6-7]. Heavy metals are hard to degrade, easy to accumulate, and highly toxic. Moreover, they can not only threaten soil quality, reduce crop yields, and lead to harvest failure, but also through the food chain to enter the human body, compromising human health [8-10]. Therefore, research on soil heavy metal pollution has received widespread attention [11-12]. According to a research report by the Ministry of Agriculture of China, which reduces its output by approximately $1.0 \times 10^{10} \mathrm{~kg}$, leading to a total loss of more than 20 billion yuan [13-14]. Some scholars have made promising findings on soil heavy metal assessment [15-17], including different scales [18-19], and different sources [20-21]. These results have important role and theoretical significance for protecting the quality of farmland soil environments and sustainable development.

Some methods for the study of heavy metal pollution have been developed and discussed in previous studies [22-24]. In terms of evaluation of soil heavy metal pollution, such as geo-accumulation index [25], Nemerow comprehensive pollution index [26] and ecological risk assessment index [27]. These methods play an important role in the assessment of soil heavy metal pollution. Spatial analysis methods can determine the distribution characteristics of heavy metals in soil, such as kriging interpolation methods [28], and inverse distance weighted interpolation [29]. In addition, Multivariate statistical analysis can be used to identify the sources of soil heavy metal pollution [30-31]. Therefore, it is effective to combine above methods to study soil heavy metals. Moreover, worldwide research on low-lying land ecosystems has mainly focused on protection and comprehensive utilization [32-34]. There are few studies on soil heavy metal pollution in lowlying land.

The Yellow River has a wide drainage area in China, and is therefore an important ecological barrier and a relevant economic zone in China [35]. Research on heavy metals in the upper reaches of the Yellow River Basin has focused on the Baotou City section [36], the source area [37], and the Lanzhou City section [38]. Research on soil heavy metals in the lower Yellow River has focused on the beach of the Lower Yellow River and the Yellow River Delta areas [39-40]. Because the Yellow River flows through the Loess Plateau in the middle reaches, carrying a large amount of sediment and silting and settling in the lower Yellow River, the river channel in the lower reaches of the Yellow River changes from deep to shallow, from narrow to wide. During the flood period, it is easy to have a breach. The strong erosion of the ground near the breach and the continuous accumulation of the river bank form different types of micro-geomorphology, such as erosion depression, sand land, sand dune and sand ridge [41]. Influenced by the "suspended river" in the lower Yellow River, low-lying land has been formed after many floods in Kaifeng, China. The low-lying land of the lower Yellow River is the area where the Yellow River due to the formation of an above-ground river, where the groundwater leaks to the side. This area is prone to soil salinity and waterlogging, serious sandy soils, and unreliable crops. However, this area is an open ecosystem, after decades of continuous transformation by human. And the low-lying land of the lower Yellow River is already the core area for grain production and the development of production capacity. This region is a cultivated land reserve in Henan Province, China, and it plays an important role in increasing the area of cultivated land and increasing grain output. Due to the unique microgeomorphology form of low-lying land, affected by the double effects of the Yellow River and human activities. With the economic development and population growth, the increasing demand for food, a large number of chemical fertilizers and pesticides are used, and the soil environment of low-lying land is polluted to a certain extent. However, research on soil environmental quality in the low-lying land of the lower Yellow River remains scarce. Whether the soil environment of lowlying land is polluted and damaged, and the degree of pollution, there are no specific data and literature to reference.

Therefore, this study sought to study the lowlying land of the Lower Yellow River depression and analyze the heavy metal contents of farmland soils that it can provide a technical support for local agricultural development and contribute to the protection of cultivated land resources. Additionally, characterizing soil heavy metal content in the aforementioned lowlying land provides a reference for soil environmental quality assessment of other low-lying land environments to facilitate the protection of watershed soil quality and food security in these ecosystems. It is helpful to judge the impact of human activities on the soil environment of low-lying land, and has some practical value. And it 
also has reference value and significance for the study of low-lying land in other regions of the world.

\section{Materials and Methods}

\section{Study Area}

The low-lying land area of the lower Yellow River is located on the southern bank of the Yellow River levee (Fig. 1). Its width ranges from approximately $1 \mathrm{~km}$ to $23 \mathrm{~km}$, it spans $95 \mathrm{~km}$ from west to east, and covers a total area of approximately $1,327.86 \mathrm{~km}^{2}$. Its land-use types are mainly agricultural, urban, and transportation, among others. The primary crops in the region are wheat, corn, peanuts, rice, and vegetables. The terrain in the study area is generally flat and low. The region exhibits a temperate continental monsoon climate, four distinct seasons, droughts in spring and autumn, more rain in summer, and less snow in winter. The annual average precipitation and temperature is $634.3 \mathrm{~mm}$ and $14^{\circ} \mathrm{C}$. The low-lying land area of the Kaifeng (Henan Province, China) section of the lower Yellow River has the advantages of being a good arable land foundation and thus having great potential for agricultural production. We utilized ecological risk assessment to confirm the risk status of soil heavy metals in the Lowlying land. This procedure has positive significance for ensuring food safety in Henan Province, consolidating the agricultural status of Henan Province, facilitating rapid agricultural development in Henan Province, China, and promoting food production.

\section{Sampling and Laboratory Analysis}

Soil samples were according to a regular $3 \times 3 \mathrm{~km}$ grid to collect. We collected 156 surface soil samples $(0-20 \mathrm{~cm})$ distributed throughout the low-lying land according to the diagonal method (Fig. 1). Each sample point was divided into four corner vertices and one center point for a total of 5 points. The samples from the 5 points were evenly mixed inside a plastic cloth to remove weeds, as well as gravel and other impurities. Afterward, $1 \mathrm{~kg}$ of the mixed soil was recovered following the quarter method, transferred to a sample bag, and brought to the laboratory. They were then allowed to ventilate and dry at room temperature. Larger pieces of gravel were crushed to ensure that they would pass a $0.84 \mathrm{~mm}$ nylon sieve. The sample was then divided into two parts via the quarter method, of which one part was stored, and the other part need get though a $0.15 \mathrm{~mm}$ nylon sieve that they were ground $20 \mathrm{~g}$.

According to China's technical specifications for soil environmental monitoring, we performed the experimental determination of the eight elements in the study area. We utilized inductively coupled plasma mass spectrometry to measure the concentrations of $\mathrm{Pb}, \mathrm{Ni}, \mathrm{Cd}, \mathrm{Zn}, \mathrm{Cu}$ and $\mathrm{Cr}$, whereas utilized atomic fluorescence spectrophotometry to measure As and $\mathrm{Hg}$ concentrations [42]. Our experiment eagents were all deemed safe and reliable. For quality control, we used national standard soil samples (GSS-2).

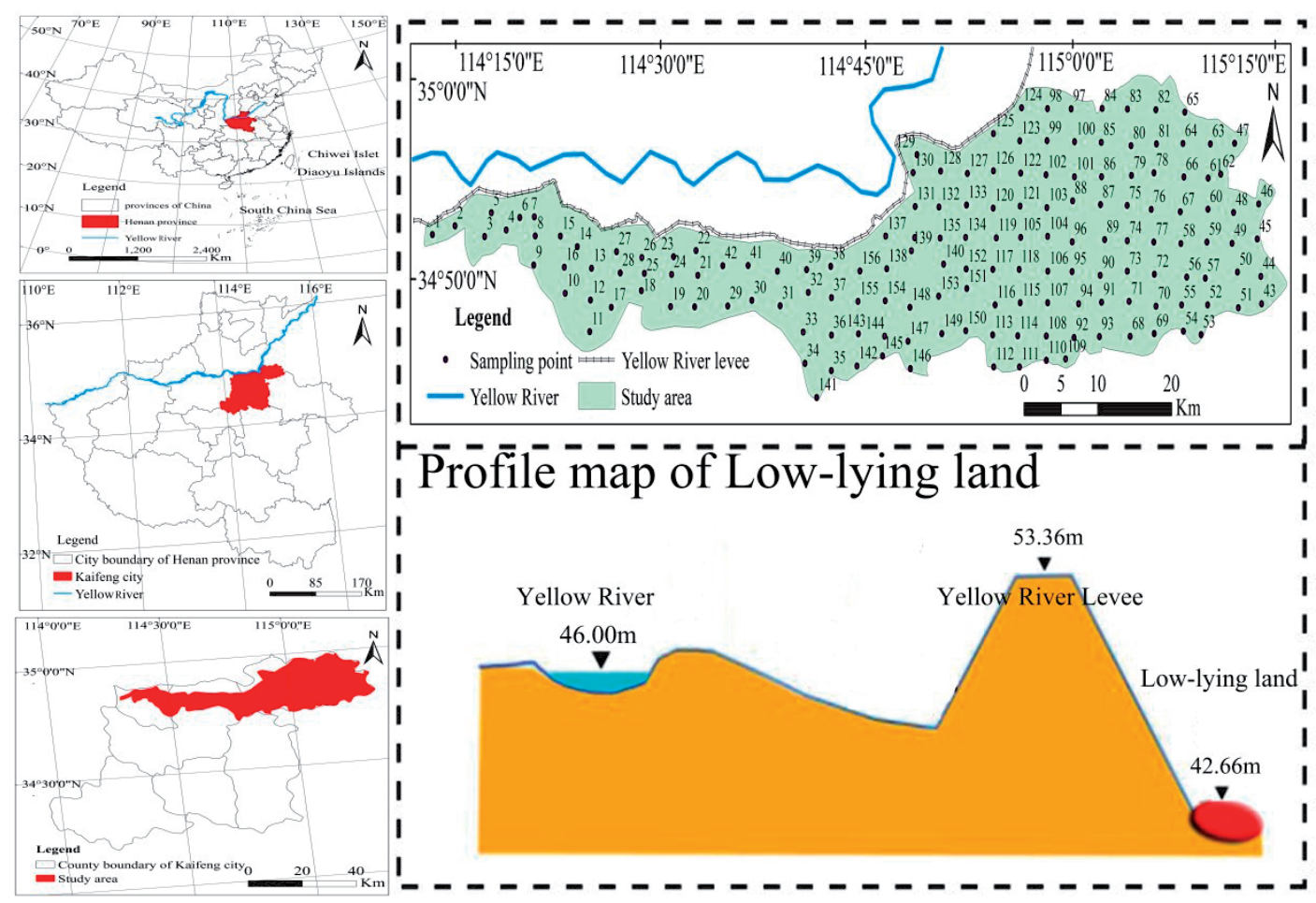

Fig. 1. Profiles and sampling points of the study area. 
Table 1. The specific situation of Nemerow pollution index.

\begin{tabular}{|c|c|c|}
\hline Class & Nemerow pollution index & Pollution Level \\
\hline 1 & $P_{\mathrm{c}} \leq 0.7$ & Safety \\
\hline 2 & $0.7<P_{\mathrm{c}} \leq 1$ & Precaution \\
\hline 3 & $1<P_{\mathrm{c}} \leq 2$ & Slightly polluted \\
\hline 4 & $2<P_{\mathrm{c}} \leq 3$ & Moderately polluted \\
\hline 5 & $P_{\mathrm{c}}>3$ & Seriously polluted \\
\hline
\end{tabular}

Methods

\section{Nemerow Comprehensive Pollution Index}

A single factor index method is the most basic and widely used method to evaluate the pollution degree of a pollutant in soil on the basis of soil environmental quality standard. And its objective is clear and easy to calculate, but it can only evaluate the single element of heavy metal in the soil, which can not reflect the comprehensive situation of soil pollution [43]. The Nemerow comprehensive pollution index method is considering not only the maximum value of the pollutants, but also the average value of the pollutants, the pollution status of heavy metals in the soil can be more objectively evaluated [44-45]. The calculation formula is:

$$
\begin{gathered}
P_{i}=\frac{C_{i}}{S_{i}} \\
P_{C}=\frac{\sqrt{\left(\frac{1}{\mathrm{n}} \sum_{i=1}^{n} P_{i}\right)^{2}+P_{i \max }^{2}}}{2}
\end{gathered}
$$

...where $P_{i}$ is the single item element $i$ pollution index, $C_{i}$ is the actual value forelement $i, S_{i}$ is the standard value of fluvo-aquic soil $i$ in Henan Province, $P_{c}$ is the comprehensive item heavy metal, and $P_{\text {imax }}$ is the maximum value of the single item of element $i$.

The single factor pollution index classification standard is the following [46]: $P_{i} \leq 1$, not polluted; $1<P_{i} \leq 2$, slightly polluted; $2<P_{i} \leq 3$, moderately polluted; $3<P$, heavily polluted. The Nemerow pollution index classification standard has five domains [26], as shown in Table 1.

\section{Ecological Risk Assessment}

Potential ecological risk index method was proposed by Swedish geochemist Hakanson to evaluate the potential risk of heavy metals in sediments [47]. This model does not only consider the role and impact of heavy metals but also combines toxicological evaluation indicators, which is suitable for the evaluation of soil heavy metals in large areas [48-49]. It can be calculated as:

$$
\begin{gathered}
R I=\sum_{i=1}^{m} E_{r}^{i}=\sum_{i=1}^{m} T_{r}^{i} \times C_{n}^{i}=\sum_{i=1}^{m} T_{r}^{i} \times \frac{c_{j}^{i}}{c_{r}^{i}} \\
E_{r}^{i}=T_{r}^{i} \times C_{n}^{i} \\
C_{n}^{i}=\frac{c_{j}^{i}}{c_{r}^{i}}
\end{gathered}
$$

...where $E_{r}^{i}$ is the individual potential ecological risk index of element $i ; T_{r}^{i}$ is the toxicity coefficient of elementl $i$ [50] (Table 2); $C_{n}{ }^{i}$ is the pollution coefficient of element $i ; c_{j}^{i}$ represents the actual values of element $i$; $c_{r}{ }_{r}^{i}$ is the reference value of element $i$ in fluvo-aquic soil in Henan Province; $R I$ is the comprehensive index.

We based on the sum of the maximum toxicity coefficient and the toxic response coefficient to assessment standard of the potential ecological risk The different types and quantities of pollutants involved in the assessment will result in different value, the more elements involved, the stronger the toxicity and the greater the RI value [51]. This study was graded according to Hakanson's (1980) grading criteria, shown in Table 3.

\section{Deterministic Interpolation and Geostatistical Kriging Interpolation}

Spatial interpolation refers to the process of estimating the value of other points using the values of known points. In geographic information system (GIS), it is mainly used to estimate the value of each pixel in the grid. Therefore, spatial interpolation is to convert point data into surface data. A method that can be used for spatial analysis and modeling. The types of spatial interpolation generally include deterministic interpolation and geostatistical Kriging interpolation. Deterministic interpolation is based on studying internal similarities, or on the basis of smoothness, using known point values as the basis to create a surface. Deterministic interpolation is mainly divided into two types: global interpolation and local interpolation. Among them, global interpolation mainly includes global polynomial interpolation (GPI); local interpolation mainly includes inverse distance weighted interpolation (IDW), radial basis function interpolation

Table 2. Toxicity response coefficients.

\begin{tabular}{|c|c|c|c|c|c|c|c|c|}
\hline Elements & $\mathrm{Pb}$ & $\mathrm{Cd}$ & $\mathrm{Zn}$ & $\mathrm{As}$ & $\mathrm{Hg}$ & $\mathrm{Cu}$ & $\mathrm{Ni}$ & $\mathrm{Cr}$ \\
\hline Coefficient of toxicity & 5 & 30 & 1 & 10 & 40 & 5 & 5 & 2 \\
\hline
\end{tabular}


Table 3. Potential ecological risk classification criteria employed in this study.

\begin{tabular}{|c|c|c|}
\hline$E_{r}{ }^{i}$ & $R I$ & Pollution Level \\
\hline$<40$ & $<110$ & Low potential risk \\
\hline $40 \sim 80$ & $110 \sim 220$ & Moderate potential risk \\
\hline $80 \sim 160$ & $220 \sim 440$ & Strong potential risk \\
\hline $160 \sim 320$ & $440 \sim 880$ & Very strong potential risk \\
\hline$>320$ & $>880$ & Extremely strong potential risk \\
\hline
\end{tabular}

(RBF) and local polynomial interpolation (LPI). Kriging method is based on spatial autocorrelation, using the original data and the structure of the semi-variance function, the unbiased interpolation method of unknown sampling points of regional variation is the main method in geostatistics. When estimating the value of unknown samples, it can comprehensively consider the data of known points, data of nearby points, spatial location and distance, etc. Compared with other methods, it is more accurate and more realistic. Under different research areas, research conditions and research purposes, Kriging interpolation method has developed a variety of methods to meet research needs. The main Kriging methods involved in this article are: Ordinary Kriging interpolation method (OK), Universal Kriging interpolation method (UK), and Disjunctive Kriging interpolation method (DK). By comparing the above six interpolation methods, the optimal interpolation model was selected for the analysis of the spatial distribution characteristics of the heavy metal content in eight soils in the study area. Inverse distance weighted interpolation (IDW) can comprehensively reflect extreme value information and spatial distribution of element content in great detail [52-53]. This method is depended on the first law of geography, whereby two objects that are close to each other are more likely to share similar properties. In this study, utilizing the IDW to study the spatial distribution of single factor index method, Nemerow comprehensive pollution index and Potential ecological risk index method.

\section{Multivariate Statistical Analysis}

Currently, most studies on soil heavy metal sources use multivariate statistical analysis methods [54-55]. Therefore, this study used correlation analysis and principal component analysis in conjunction with the SPSS 20.0 software (https://www.ibm.com/products/ spss-statistics) to distinguish the sources of soil heavy metal pollution and offer a theoretical foundation for soil heavy metal pollution control.

\section{Results and Discussion}

\section{Descriptive Statistical Analysis and Content Analysis}

In this study, using the SPSS 20.0 software to perform descriptive statistical research on soil heavy metal content data from 156 sampling points in this study area, and Kolmogorov-Smirnov method was used to test the normal distribution of heavy metals in soil (Table 4).

Table 4. Concentration statistics of heavy metals.

\begin{tabular}{|c|c|c|c|c|c|c|c|c|c|c|c|}
\hline $\begin{array}{c}\text { Heavy } \\
\text { metal }\end{array}$ & $\begin{array}{c}\text { Min. } \\
(\mathrm{mg} / \mathrm{kg})\end{array}$ & $\begin{array}{c}\text { Average } \\
(\mathrm{mg} / \mathrm{kg})\end{array}$ & $\begin{array}{c}\text { Max. } \\
(\mathrm{mg} / \mathrm{kg})\end{array}$ & $\begin{array}{c}\text { Standard } \\
\text { deviation }\end{array}$ & Variance & K-S test & CV $(\%)$ & Skewness & Kurtosis & $\begin{array}{c}\text { Background } \\
\text { value* }\end{array}$ & $\begin{array}{c}\text { Percentage } \\
\text { overthe } \\
\text { standard } \\
\text { rate }(\%)\end{array}$ \\
\hline $\mathrm{Cu}$ & 8.000 & 17.122 & 64.000 & 6.103 & 37.248 & $\begin{array}{c}\text { Lognormal } \\
\text { distribution }\end{array}$ & 35.600 & 3.454 & 22.094 & 24.100 & 10.260 \\
\hline $\mathrm{Cr}$ & 22.200 & 53.173 & 93.500 & 14.406 & 207.540 & $\begin{array}{c}\text { Normal } \\
\text { distribution }\end{array}$ & 27.100 & -0.091 & -0.130 & 66.600 & 16.030 \\
\hline $\mathrm{Ni}$ & 13.000 & 24.979 & 47.00 & 5.115 & 26.162 & $\begin{array}{c}\text { Normal } \\
\text { distribution }\end{array}$ & 20.500 & 1.259 & 3.626 & 29.600 & 14.100 \\
\hline $\mathrm{Zn}$ & 32.100 & 56.371 & 187.000 & 14.691 & 215.815 & $\begin{array}{c}\text { Lognormal } \\
\text { distribution }\end{array}$ & 26.100 & 4.810 & 39.922 & 71.100 & 7.050 \\
\hline $\mathrm{Pb}$ & 10.700 & 17.631 & 45.900 & 4.045 & 16.365 & $\begin{array}{c}\text { Non-normal } \\
\text { distribution }\end{array}$ & 22.900 & 3.424 & 17.889 & 21.900 & 9.620 \\
\hline $\mathrm{Cd}$ & 0.080 & 0.166 & 0.770 & 0.068 & 0.005 & $\begin{array}{c}\text { Lognormal } \\
\text { distribution }\end{array}$ & 41.000 & 4.830 & 39.852 & 0.100 & 95.150 \\
\hline $\mathrm{As}$ & 2.900 & 9.514 & 18.600 & 2.719 & 7.391 & $\begin{array}{c}\text { Normal } \\
\text { distribution }\end{array}$ & 28.600 & 0.301 & 0.496 & 9.700 & 48.080 \\
\hline $\mathrm{Hg}$ & 0.003 & 0.042 & 0.311 & 0.045 & 0.002 & $\begin{array}{c}\text { Lognormal } \\
\text { distribution }\end{array}$ & 108.4 & 3.805 & 17.024 & 0.047 & 21.790 \\
\hline
\end{tabular}

Note: CV shows coefficient of variation; * shows Background value of fluvo-aquic soil in Henan Province 
Table 4 shows that only the average $\mathrm{Cd}$ content exceeded the background value in the study area, manifesting that the soil quality was good. According to the heavy metal study analysis in 156 soil samples, the maximum exceeding rate of $\mathrm{Cd}$ was $95.51 \%$, and the exceeding rates of other heavy metal elements were As $\quad(48.08 \%)>\mathrm{Hg} \quad(21.79 \%)>\mathrm{Cr} \quad(16.03 \%)>\mathrm{Ni}$ $(14.10 \%)>\mathrm{Cu} \quad(10.26 \%)>\mathrm{Pb} \quad(9.62 \%)>\mathrm{Zn} \quad(7.05 \%)$, indicating that $\mathrm{Cd}$ and $\mathrm{As}$ were the most serious pollutants in the low-lying land. The coefficient of variation $(\mathrm{CV})$ is the ratio of the standard deviation of the original data to the average of the original data, indicating the dispersion degree of the data. $\mathrm{CV}$ of soil heavy metals were $\mathrm{Hg}(108.4 \%)>\mathrm{Cd}(41 \%)$ $>\mathrm{Cu} \quad(35.6 \%)>\mathrm{As} \quad(28.6 \%)>\mathrm{Cr} \quad(27.1 \%)>\mathrm{Zn} \quad(26.1 \%)$ $>\mathrm{Pb}(22.9 \%)>\mathrm{Ni}(20.5 \%)$. Basing on the classification of the $\mathrm{CV}$ by Wilding [56], $\mathrm{CV} \leq 0.1$ represent weak variability, $0.1<\mathrm{CV}<1$ represent medium variability, and $\mathrm{CV} \geq 1$ represent strong variability. According to these classification criteria, $\mathrm{Hg}$ exhibited strong variability whereas the other seven heavy metals presented medium variability. This suggests that $\mathrm{Hg}$ is strongly affected by external disturbances and is greatly affected by human activities. For example, industrial activities and the excessive use of fertilizers. The normal distribution of 8 heavy metals was tested by the KS method. The results showed that $\mathrm{Cr}, \mathrm{Ni}$ and As were normally distributed, $\mathrm{Cu}, \mathrm{Zn}, \mathrm{Cd}$ and $\mathrm{Hg}$ were lognormally distributed. $\mathrm{Pb}$ still did not meet the positive distribution after taking logarithm State distribution, therefore, it is not possible to use geostatistical Kriging interpolation for $\mathrm{Pb}$ space interpolation, but random model interpolation can be used.

\section{Pollution Evaluation and Analysis of Spatial Interpolation Results}

\section{Comparison between Deterministic Interpolation and Geostatistical Kriging Interpolation}

The selection of the optimal model needs to compare the average error, root mean square error and average standard deviation under different models. When the average prediction error is close to 0 , it means that the prediction error is unbiased and optimal, but the size of the data will affect the average error. If it is affected, the closer the standard average error is to 0 , the better; if the average error is close to the root mean square prediction error, the prediction standard deviation is effective, that is, the standardized root mean square error should be close to 1 , and the prediction error can be judged Whether it is optimal. Therefore, the optimal model can be fitted when the standard average error (ME) is closest to 0; when the normalized root mean square error (RMSE) is nearest to 1 ; when the RMES and the ME are close and the minimum, the optimal model can be fitted.

According to the geostatistics analysis tool of ArcGIS 10.2 software, the inverse distance weighted interpolation method, global polynomial interpolation

Table 5. Optimal selection of deterministic interpolation and Kriging interpolation methods for heavy metal elements in soil.

\begin{tabular}{|c|c|c|c|c|}
\hline Elements & Parameter & Interpolation method & ME & RMSE \\
\hline \multirow{2}{*}{$\mathrm{Cu}$} & IS & $\mathrm{RBF}$ & -0.076 & 6.101 \\
\hline & Constant & DK & -0.216 & 6.002 \\
\hline \multirow{2}{*}{$\mathrm{Cr}$} & IS & $\mathrm{RBF}$ & -0.506 & 14.329 \\
\hline & Order 2 & DK & -0.006 & 14.237 \\
\hline \multirow{2}{*}{$\mathrm{Ni}$} & IS & $\mathrm{RBF}$ & -0.123 & 4.625 \\
\hline & Order 2 & $\mathrm{OK}$ & -0.058 & 4.631 \\
\hline \multirow{2}{*}{$\mathrm{Zn}$} & Order 4 & GPI & 1.259 & 13.600 \\
\hline & Order 1 & UK & 0.189 & 14.669 \\
\hline \multirow{2}{*}{$\mathrm{Cd}$} & SWT & $\mathrm{RBF}$ & 0.003 & 0.062 \\
\hline & Order 1 & UK & -0.001 & 0.056 \\
\hline \multirow{2}{*}{ As } & IS & $\mathrm{RBF}$ & -0.044 & 2.587 \\
\hline & Constant & UK & 0.008 & 2.603 \\
\hline \multirow{2}{*}{$\mathrm{Hg}$} & IS & $\mathrm{RBF}$ & -0.003 & 0.045 \\
\hline & Order 1 & UK & -0.002 & 0.045 \\
\hline $\mathrm{Pb}$ & IS & $\mathrm{RBF}$ & 0.063 & 3.885 \\
\hline
\end{tabular}

Note: GPI: global polynomial interpolation; RBF: radial basis function interpolation; SWT: tension spline function interpolation; IS: anti high degree surface spline function; OK: Ordinary Kriging interpolation method; UK: Universal Kriging interpolation method; DK: Disjunctive Kriging interpolation method. 
method and radial basis function interpolation method are OK, UK and DK in geostatistics. Three Kriging interpolation methods were used to determine the optimal interpolation method of 8 heavy metal elements in the soil of the study area according to the principle that the ME is closest to 0 , the RMSE is the minimum, and RMSE is given priority [57]. The results are shown in Table 5.

It can be seen from Table 5 that the root mean square error of the DK under constant conditions is less than that radial basis interpolation method (RBF) of anti high degree surface spline function (IS); the average error of $\mathrm{Cr}$ element in the second order DK is the closest to 0 , and the RMSE is the smallest. The RMSE value PBF of IS is less than DK. The RMSE of fourth order global polynomial interpolation (GPI) of $\mathrm{Zn}$ element is less than DK method of order 1 . In the UK with the firstorder trend effect, the ME value is the closest to 0 and the RMSE value is the smallest. The RMSE value of As element in the RBF of IS is less than that of UK under constant condition. The RMSE values of $\mathrm{Hg}$ element in the in the RBF of IS and the first order in UK are equal, but the me value of the first order $\mathrm{UK}$ is closer to $0 . \mathrm{Pb}$ element does not conform to normal distribution, so it can not be used in linear Kriging interpolation method, but can be used the RBF of IS.

To sum up, the optimal interpolation methods of 8 kinds of soil heavy metal elements in the study area are: $\mathrm{Cu}$ is the $\mathrm{DK}$ of constant, $\mathrm{Cr}$ is the $\mathrm{DK}$ of order $2, \mathrm{Ni}$ is RBF of IS, $\mathrm{Zn}$ is the GPI of order $4, \mathrm{Cd}$ is the UK of order 1 , As is the RBF of IS, Hg is the UK of order 1, $\mathrm{Pb}$ is $\mathrm{RBF}$ of IS.

\section{Spatial Distribution Variation}

According to the comparison of deterministic interpolation and Kriging interpolation in Table 5 under different parameters, the optimal interpolation method of eight heavy metal elements as obtained. The spatial distribution map of eight heavy metal elements in soil was obtained by using the optimal spatial interpolation model and the interpolation analysis tool of ArcGIS 10.2 software (Fig. 2).

Overall, the eight elements exhibited higher concentrations in the west, with lower concentrations in the east (Fig. 2). Moreover, all heavy metals presented
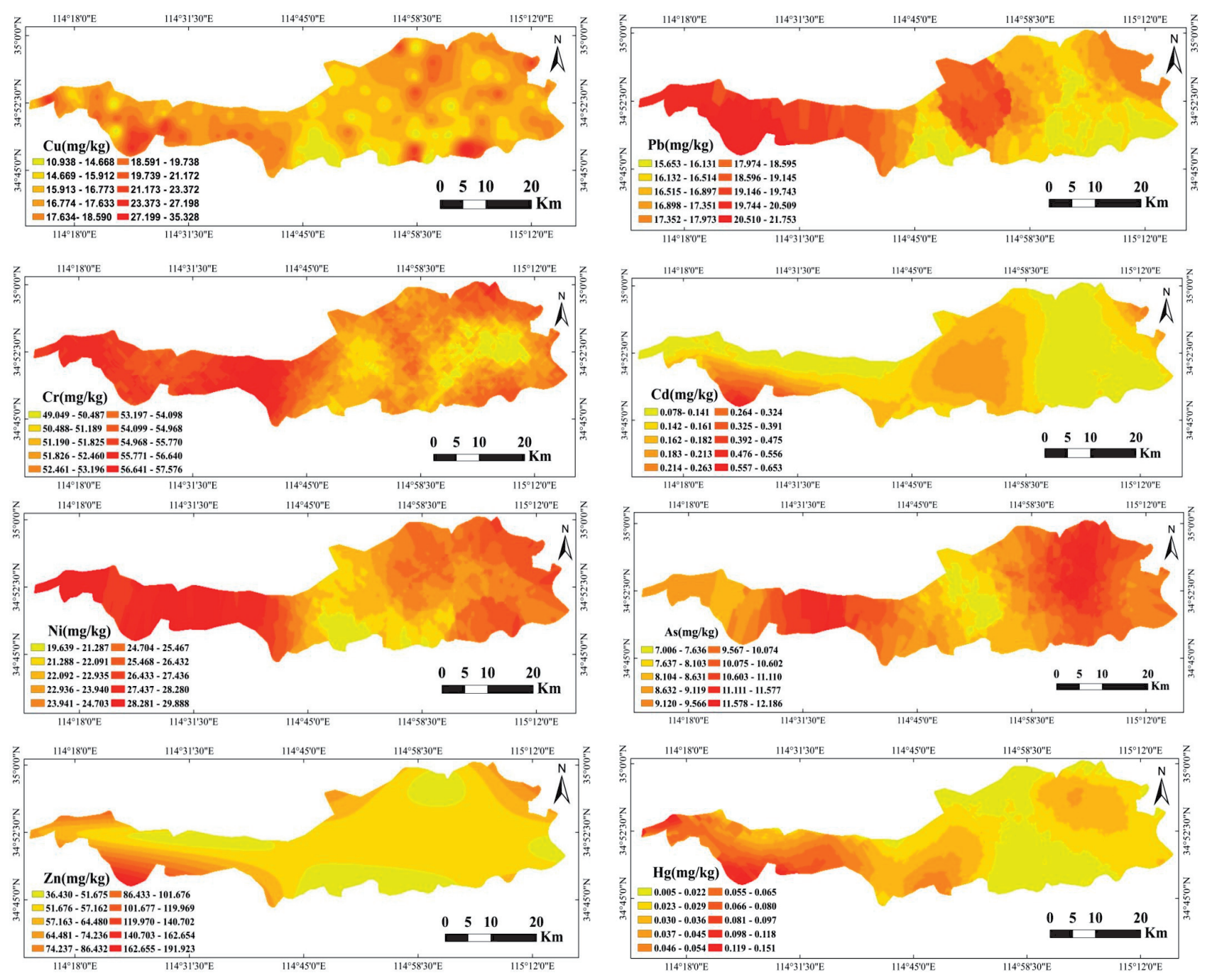

Fig. 2. Spatial distribution of heavy metal $(\mathrm{Cu}, \mathrm{Cr}, \mathrm{Ni}, \mathrm{Zn}, \mathrm{Pb}, \mathrm{Cd}, \mathrm{As}$, and $\mathrm{Hg})$ content. 
Table 6. Descriptive statistics of single factor pollution index.

\begin{tabular}{|c|c|c|c|c|c|c|c|}
\hline Elements & $\begin{array}{c}\text { Minimum } \\
{[\mathrm{mg} / \mathrm{kg}]}\end{array}$ & $\begin{array}{c}\text { Average } \\
{[\mathrm{mg} / \mathrm{kg}]}\end{array}$ & $\begin{array}{c}\text { Maximum } \\
{[\mathrm{mg} / \mathrm{kg}]}\end{array}$ & $\begin{array}{c}\text { Standard } \\
\text { deviation }\end{array}$ & Variance & Skewness & Kurtosis \\
\hline $\mathrm{Cu}$ & 0.33 & 0.71 & 2.66 & 0.25 & 0.06 & 3.45 & 22.09 \\
\hline $\mathrm{Cr}$ & 0.33 & 0.8 & 1.4 & 0.22 & 0.05 & -0.09 & -0.13 \\
\hline $\mathrm{Ni}$ & 0.44 & 0.84 & 1.59 & 0.17 & 0.03 & 1.26 & 3.63 \\
\hline $\mathrm{Zn}$ & 0.45 & 0.79 & 2.63 & 0.21 & 0.04 & 4.81 & 39.92 \\
\hline $\mathrm{Pb}$ & 0.49 & 0.81 & 2.1 & 0.18 & 0.03 & 3.42 & 17.89 \\
\hline $\mathrm{Cd}$ & 0.8 & 1.66 & 7.7 & 0.68 & 0.46 & 4.83 & 39.85 \\
\hline $\mathrm{As}$ & 0.29 & 0.98 & 1.92 & 0.28 & 0.08 & 0.3 & 0.5 \\
\hline $\mathrm{Hg}$ & 0.06 & 0.89 & 6.62 & 0.96 & 0.92 & 3.81 & 17.02 \\
\hline
\end{tabular}

high concentration areas, suggesting the influence of human activities. The spatial variation of $\mathrm{Zn}, \mathrm{Cd}, \mathrm{Pb}$, $\mathrm{Hg}$, and $\mathrm{Cu}$ were similar. The area with the highest heavy metal concentrations were mainly located in the southwest area of the low-lying land, which was close to residential and industrial areas. $\mathrm{Cr}, \mathrm{Ni}$, and $\mathrm{As}$ also presented similar spatial distribution characteristics, which were found to be mainly sporadic, suggesting that it existed point source pollution. The heavy metal concentrations of western area of the low-lying land presented higher than the eastern area, likely because the western region encompasses a suburb of Kaifeng that is close to a coal chemical industrial area. This area also presents abundant industrial waste and automobile exhaust emissions, as well as garbage from households.

\section{Pollution Assessment and Analysis of Spatial Distribution}

Using the SPSS 20.0 software, descriptive statistical analysis were performed on the single factor pollution index of eight elements (Table 6).

Table 6 shows that among single factor pollution index of the eight elements examined herein, only the average value of $\mathrm{Cd}$ exceeded 1 . According to the evaluation criteria, $\mathrm{Cd}$ concentrations fell within the slightly polluted classification. The average values of the remaining seven elements (i.e. $\mathrm{Zn}, \mathrm{Hg}, \mathrm{As}, \mathrm{Ni}, \mathrm{Pb}$, $\mathrm{Cu}$ and $\mathrm{Cr}$ ) were all less than 1, showing that they were within a safe level. The average value of As was 0.98, which is very close to the light pollution classification threshold. When accounting for maximum values of all heavy metals, the single factor pollution index examined herein exceeded 1 and therefore surpassed the threshold of light pollution. Notably, 7.7 and 6.62 were taken asmaximum values of $\mathrm{Cd}$ and $\mathrm{Hg}$, reaching the heavily contaminated classification, and $\mathrm{Cu}, \mathrm{Zn}$, and $\mathrm{Pb}$ reached the moderately contaminated threshold. These observations demonstrate that the eight soil heavy metals exhibited different degrees of pollution severity.

The individual pollution indexes of the eight heavy metals were determined basing on grading standard of the single-factor pollution index. The data suggest $\mathrm{Cu}$ presented16 polluted points, and the percentage of pollution points was $10 \%$. The number of polluted points for $\mathrm{Cr}$ was 24, and the percentage of polluted points was $15 \%$. The number of polluted points for $\mathrm{Ni}$ was 21, and the percentage of polluted points was $13 \%$. The number of polluted points of $\mathrm{Zn}$ was11, the percentage of polluted points was $7 \%$. Pb had 14 polluted points, and the percentage of pollution points was $9 \%$. The total number of $\mathrm{Cd}$ polluted points was 145 , and the percentage of polluted was $93 \%$. The number of As polluted points was 73, and the total percentage of polluted points was $47 \% \mathrm{Hg}$ presented 34 polluted points, and the total percentage of polluted points was $22 \%$.

In summary, upon completing single-factor rating analysis of the eight heavy metals, found $\mathrm{Cd}$ pollution was the most widespread, followed by $\mathrm{Cr}$, $\mathrm{Ni}$, and $\mathrm{Hg}$ with a somewhat high pollution point occurrence, and finally $\mathrm{As}, \mathrm{Cu}, \mathrm{Zn}$, and $\mathrm{Pb}$, which were found to be at relatively safe levels.

According to single factor pollution index classes that the spatial interpolation was carried out via the IDW of the ArcGIS 10.2 software to characterize the spatial variation (Fig. 3).

Fig. 3 shows that with the exception of $\mathrm{Cd}$ and As, the remaining six elements (i.e. $\mathrm{Pb}, \mathrm{Cr}, \mathrm{Ni}, \mathrm{Zn}, \mathrm{Cu}$, $\mathrm{Hg}$ ) in the study area mainly fell into the non-polluting category, whereas the study area was mainly classified as slightly polluted by $\mathrm{Cd}$. This large-scale light $\mathrm{Cd}$ pollution in the study area may be overuse of pesticides and fertilizers. $\mathrm{Cr}$, $\mathrm{Ni}$, and $\mathrm{As}$ fell into the unpolluted and slightly polluted classifications. $\mathrm{Cu}, \mathrm{Zn}$, and $\mathrm{Pb}$ presented three pollution levels: unpolluted, slightly polluted, and moderately polluted. However, the area classified as moderately polluted was relatively small. $\mathrm{Cd}$ and $\mathrm{Hg}$ presented four pollution levels: unpolluted, slightly polluted, moderately polluted, and heavily polluted. The total area that was classified as heavily polluted by $\mathrm{Hg}$ was larger than that of $\mathrm{Cd}$. Most of the $\mathrm{Hg}$ heavily polluted areas were closer to village roads, where there are more passing vehicles. Therefore, 

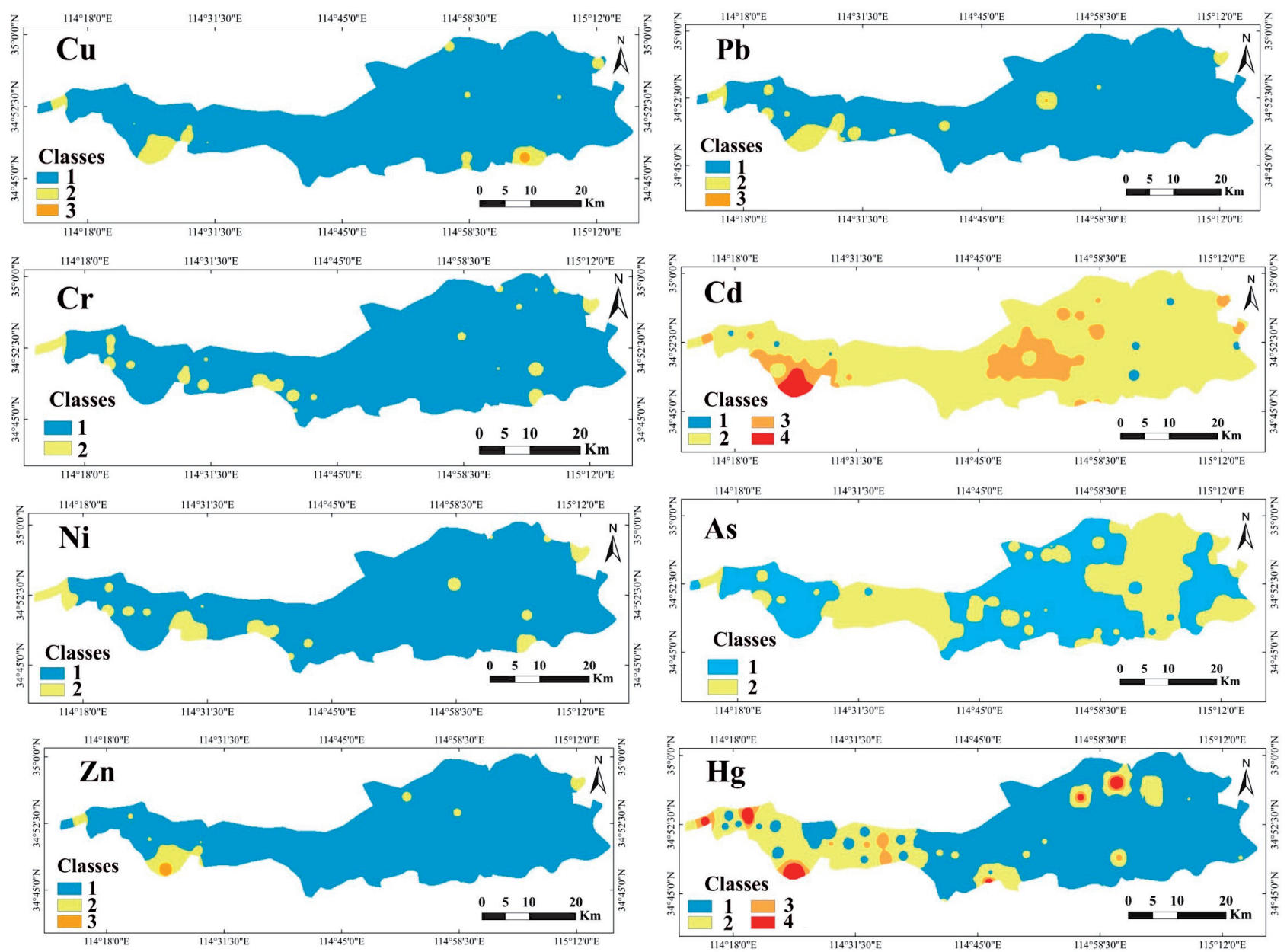

Fig. 3. Spatial distribution of single factor pollution index (Cu, Cr, Ni. Zn, $\mathrm{Pb}, \mathrm{Cd}, \mathrm{As}, \mathrm{Hg})$.

the main cause of $\mathrm{Hg}$ pollution may be automobile exhaust in said areas. $\mathrm{Cd}$ and $\mathrm{Hg}$ heavily polluted areas overlapped in the southwest region, which is a suburb with many residential areas and coal-fired enterprises $1.4 \mathrm{~km}$ away from the sampling point, suggesting that the main contributors of $\mathrm{Cd}$ and $\mathrm{Hg}$ pollution may be automobile exhaust and coal combustion in said area.

The value of the eight heavy metals were calculated according to Formula (2) to obtain the Nemerow comprehensive pollution index; the classification was then combined with the classification standard, after which the inverse distance weighted interpolation method based on the ArcGIS 10.2 software was used to make interpolation discuss on the classification results, as shown in Fig. 4.

Fig. 4 shows that the Nemerow index reached five levels. Most of the areas were classified as slightly polluted, areas of precaution were very few, and areas with safety levels were negligible, indicating widespread pollution of the soil in the study area. Heavily polluted

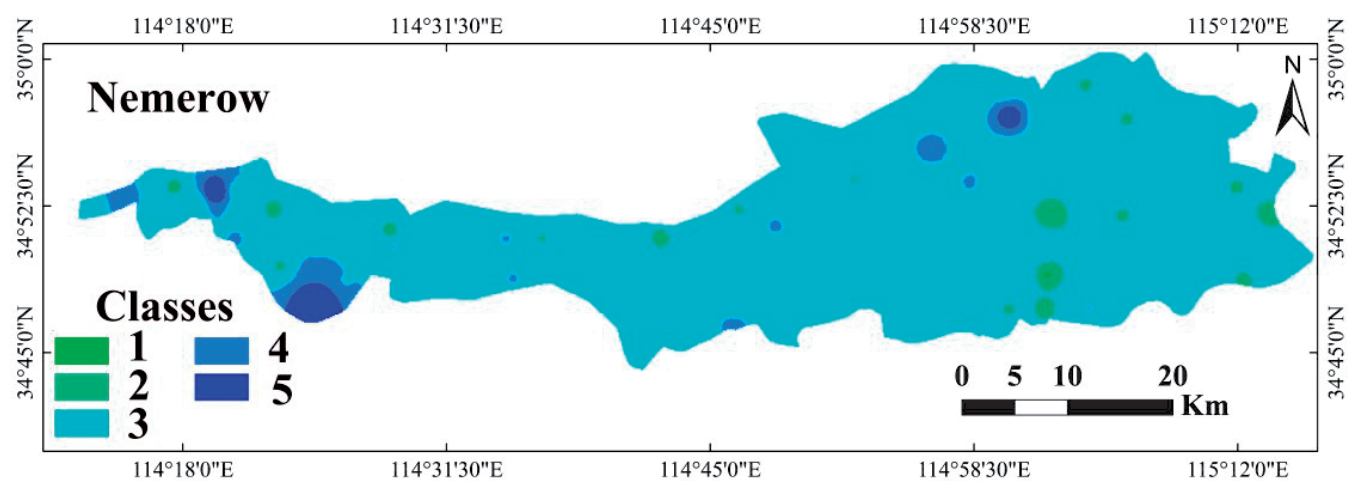

Fig. 4. Spatial distribution of Nemerow pollution index. 
Table 7. Descriptive statistical results of soil heavy metal potential risk assessment.

\begin{tabular}{|c|c|c|c|c|c|c|c|c|c|}
\hline Variables & $\mathrm{Cu}$ & $\mathrm{Cr}$ & $\mathrm{Ni}$ & $\mathrm{Zn}$ & $\mathrm{Pb}$ & $\mathrm{Cd}$ & $\mathrm{As}$ & $\mathrm{Hg}$ & $\mathrm{RI}$ \\
\hline Minimum $[\mathrm{mg} / \mathrm{kg}]$ & 1.66 & 0.67 & 2.20 & 0.45 & 2.44 & 24.00 & 2.99 & 2.55 & 44.43 \\
\hline Maximum $[\mathrm{mg} / \mathrm{kg}]$ & 13.28 & 2.81 & 7.94 & 2.63 & 10.48 & 231.00 & 19.18 & 264.68 & 496.93 \\
\hline Average $[\mathrm{mg} / \mathrm{kg}]$ & 3.55 & 1.60 & 4.22 & 0.79 & 4.03 & 49.73 & 9.80 & 35.44 & 109.17 \\
\hline Standard deviation & 1.27 & 0.43 & 0.86 & 0.21 & 0.92 & 20.36 & 2.80 & 38.41 & 52.51 \\
\hline Variance & 1.60 & 0.19 & 0.75 & 0.04 & 0.85 & 415.98 & 7.86 & 1475.00 & 2757.76 \\
\hline Skewness & 3.45 & -0.09 & 1.26 & 4.81 & 3.42 & 4.83 & 0.30 & 3.81 & 3.96 \\
\hline Kurtosis & 22.09 & -0.13 & 3.63 & 39.92 & 17.89 & 39.85 & 0.50 & 17.02 & 22.41 \\
\hline Pollution degree & Low risk & Low risk & Low risk & Low risk & Low risk & Moderate risk & Low risk & Low risk & Low risk \\
\hline
\end{tabular}

areas coincided with regions with industrial activity, motorized transportation, densely populated residential areas, widespread human activities, automobile exhaust, industrial wastewater, domestic waste, and use of pesticides and fertilizers, all of which may have contributed to the pollution.

\section{Evaluation of Potential Ecological Risk Indexes and Research of Spatial Distribution Characteristics}

The reference value selected in the study is based on the background value of the fluvo-aquic soil in Henan Province, which can better reflect the regional differentiation. The potential ecological risk index value is based on the formula (3) to calculate using the SPSS 20.0 software and, according to the grading standards (Table 3), the ecological environment risk index value was subjected to descriptive statistical analysis and hierarchical evaluation. The results are shown in Table 7.

Table 7 shows that only $\mathrm{Cd}$ presented a moderate risk, whereas the other seven were all classified as having low risk. An comprehensive RI determined that the study area presented a low risk, indicating that heavy metal pollution poses a low environmental risk, most of which is attributable to $\mathrm{Cd}$ pollution. From a maximum value perspective, only $\mathrm{Cd}$ and $\mathrm{Hg}$ exceeded a value of 40 , reaching values of 231 and 264.68, respectively, both of which were classified as having a very strong risk potential. The maximum values of the other six elements were classified as having a low risk that the reason was value less than 40 . This indicates that $\mathrm{Cd}$ and $\mathrm{Hg}$ present strong risks to different degrees, which is related to the higher toxicity of $\mathrm{Cd}$ and $\mathrm{Hg}$. Taking the minimum value as reference, all eight heavy metals examined in soil were below a value of 40 , which is associated with a low risk. The maximum value of the RI was 496.93, which corresponds with a very strong risk, according to the classification standard. The RI also exhibited strong risks at different levels, which was mainly reason what because the maximum values of $\mathrm{Hg}$ and $\mathrm{Cd}$ were large.

IDW of the ArcGIS 10.2 software was used to make interpolation research on the classification results to obtain a potential ecological pollution index classification map, as shown in Fig. 5.

Fig. 5 shows that the potential ecological risk index level was mainly dominated by low risk areas, followed by moderate risk areas. Only a few strong risk areas were identified, very strong risk areas were negligible. Low risk areas were mainly concentrated in the eastern region, specifically in the Lankao County (Kaifeng, China) area. Ecological risk was mainly moderate in the western area of the low-lying land, where corresponds

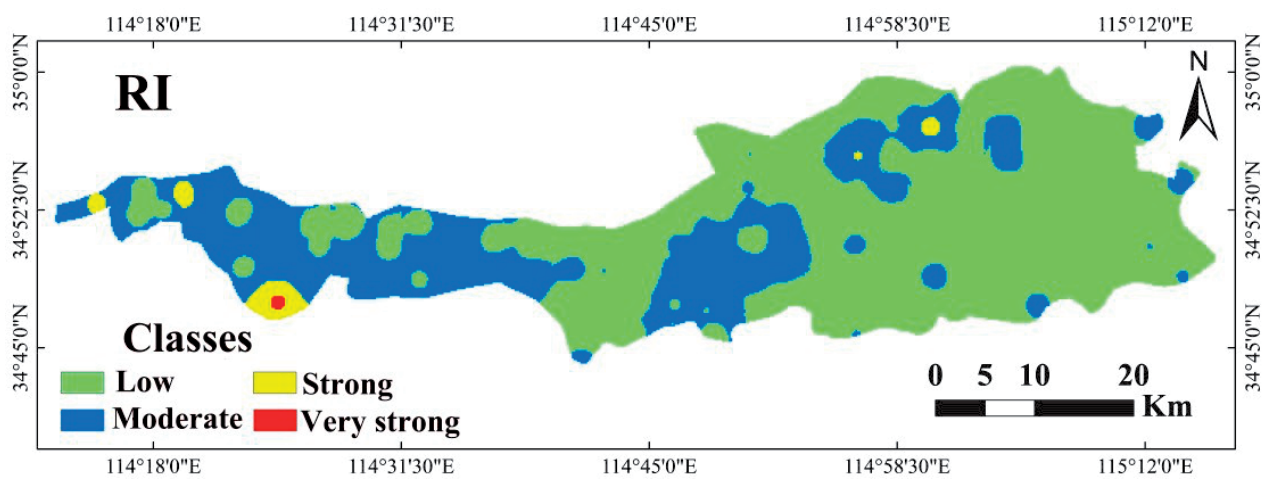

Fig. 5. Spatial distribution of potential ecological risk index. 
Table 8. Results of the correlation analysis.

\begin{tabular}{|c|c|c|c|c|c|c|c|c|}
\hline Elements & $\mathrm{Cu}$ & $\mathrm{Cr}$ & $\mathrm{Ni}$ & $\mathrm{Zn}$ & $\mathrm{Pb}$ & $\mathrm{Cd}$ & $\mathrm{As}$ & $\mathrm{Hg}$ \\
\hline $\mathrm{Cu}$ & 1 & & & & & & & \\
\hline $\mathrm{Cr}$ & $0.346^{* *}$ & 1 & & & & & & \\
\hline $\mathrm{Ni}$ & $0.607^{* *}$ & $0.704^{* *}$ & 1 & & & & & \\
\hline $\mathrm{Zn}$ & $0.571^{* *}$ & $0.443^{* *}$ & $0.584^{* *}$ & 1 & & & & \\
\hline $\mathrm{Pb}$ & $0.485^{* *}$ & $0.408^{* *}$ & $0.588^{* *}$ & $0.682^{* *}$ & 1 & & & \\
\hline $\mathrm{Cd}$ & $0.402^{* *}$ & $0.272^{* *}$ & $0.289^{* *}$ & $0.808^{* *}$ & $0.623^{* *}$ & 1 & & \\
\hline $\mathrm{As}$ & $0.341^{* *}$ & $0.499^{* *}$ & $0.565^{* *}$ & $0.292^{* *}$ & $0.195^{*}$ & 0.091 & 1 & \\
\hline $\mathrm{Hg}$ & $0.222^{* *}$ & $0.167 *$ & $0.195^{*}$ & $0.439 * *$ & $0.362^{* *}$ & $0.437 * *$ & 0.037 & 1 \\
\hline
\end{tabular}

Note: ** indicates significant correlation at a 0.01 level; * indicates significant correlation at a 0.05 level.

Table 9. Principal component analysis results.

\begin{tabular}{|c|c|c|c|c|c|c|c|c|c|}
\hline \multirow{2}{*}{ Factor } & \multicolumn{3}{|c|}{ Initial eigenvalue } & \multicolumn{3}{c|}{ Extract square sum load } & \multicolumn{3}{c|}{ Rotate square sum load } \\
\cline { 2 - 10 } & Eigenalues & $\begin{array}{c}\text { Variance } \\
(\%)\end{array}$ & $\begin{array}{c}\text { Cumulative } \\
\text { Variance(\%) }\end{array}$ & Eigenvalues & $\begin{array}{c}\text { Variance } \\
(\%)\end{array}$ & $\begin{array}{c}\text { Cumulative } \\
\text { Variance (\%) }\end{array}$ & Eigenvalues & $\begin{array}{c}\text { Variance } \\
(\%)\end{array}$ & $\begin{array}{c}\text { Cumulative } \\
\text { Variance (\%) }\end{array}$ \\
\hline 1 & 4.037 & 50.458 & 50.458 & 4.037 & 50.458 & 50.458 & 2.832 & 35.403 & 35.403 \\
\hline 2 & 1.460 & 18.253 & 68.711 & 1.460 & 18.253 & 68.711 & 2.665 & 33.308 & 68.711 \\
\hline 3 & 0.709 & 8.863 & 77.757 & & & & & & \\
\hline 4 & 0.589 & 7.360 & 84.935 & & & & & & \\
\hline 5 & 0.512 & 6.401 & 91.336 & & & & & & \\
\hline 6 & 0.373 & 4.662 & 95.998 & & & & & & \\
\hline 7 & 0.209 & 2.614 & 98.612 & & & & & & \\
\hline 8 & 0.111 & 1.388 & 100.00 & & & & & \\
\hline
\end{tabular}

to the suburbs of Kaifeng City. The strong and very strong risk areas corresponded with the residential regions of villages within the city. These observations demonstrate that potential ecological risks were greatly affected by human activities.

Using the SPSS 20.0 software to study correlation analysis and principal component analysis of the eight elements in the low-lying land. According to these results that we can decide source analysis of heavy metals in soil. The results are shown in Tables 8 and 9.

Table 8 shows that the correlation between $\mathrm{Cd}$ and As was weak and not significant. Meanwhile, no significant correlation between $\mathrm{As}$ and $\mathrm{Hg}$ was identified. In general, with the exception of $\mathrm{As}, \mathrm{Cd}$, and $\mathrm{Hg}$, which had no significant correlation between the eight heavy metals, other heavy metals exhibited significant or extremely significant positive correlations. These observations suggest that the pollution sources of $\mathrm{Zn}, \mathrm{Ni}, \mathrm{Cu}, \mathrm{Pb}$, and $\mathrm{Cr}$ may come from the same category.

Table 9 shows that two-component factors were extracted from eight components in the study area, and the cumulative variance was $68.711 \%$. the variance contribution rate of factor 1 (extracted square sum) was $50.458 \%$, and the variance contribution factor of factor 2 (extracted square sum) was $18.253 \%$. The factor load matrix is more clearly distributed after rotation (Table 10), which can better explain the meaning

Table 10. Comparative analysis between factor loadings and extraction sums of squared loadings.

\begin{tabular}{|c|c|c|c|c|}
\hline \multirow{2}{*}{ Elements } & \multicolumn{2}{|l|}{ Component matrix } & \multicolumn{2}{c|}{ Rotation component matrix } \\
\cline { 2 - 5 } & $\mathrm{PC} 1$ & $\mathrm{PC} 2$ & $\mathrm{PC} 1$ & $\mathrm{PC} 2$ \\
\hline $\mathrm{Cu}$ & 0.877 & -0.27 & 0.465 & 0.554 \\
\hline $\mathrm{Cr}$ & 0.816 & 0.416 & 0.190 & 0.791 \\
\hline $\mathrm{Ni}$ & 0.796 & -0.224 & 0.311 & 0.862 \\
\hline $\mathrm{Zn}$ & 0.718 & 0.086 & 0.825 & 0.402 \\
\hline $\mathrm{Pb}$ & 0.714 & -0.530 & 0.735 & 0.381 \\
\hline $\mathrm{Cd}$ & 0.679 & 0.447 & 0.883 & 0.101 \\
\hline $\mathrm{As}$ & 0.507 & 0.647 & -0.073 & 0.819 \\
\hline $\mathrm{Hg}$ & 0.473 & -0.506 & 0.691 & -0.046 \\
\hline
\end{tabular}


of each factor than when rotation was not applied. Therefore, load matrix rotation was used to interpret and analyze the eight heavy metals. $\mathrm{Zn}, \mathrm{Pb}, \mathrm{Cd}$, and $\mathrm{Hg}$ with larger load values in the first principal component (PC1) exhibited a variance contribution rate of $35.403 \%$, suggesting that the pollution sources of these four elements may be the same; the second main component (PC2) had larger load values for $\mathrm{Ni}$, $\mathrm{Cr}, \mathrm{Cu}$, and $\mathrm{As}$, and the variance contribution rate was $33.308 \%$, suggesting that these four heavy metals may share similar sources. Compared with the results of the correlation analysis, only As had no significant correlation with $\mathrm{Pb}$ and $\mathrm{Hg}$, further suggesting that the pollution sources of these two groups of factors are the same or similar.

Combined with the previous analysis, only the average $\mathrm{Cd}$ concentration exceeded the background value, and the rate of sample exceeding the standard reached $95.51 \%$. Cd is often used as an indicator of excessive fertilizer and pesticide use [58], and therefore the occurrence of $\mathrm{Cd}$ is linked to human activities. Regarding the degree of variation, the coefficient of variability of $\mathrm{Hg}$ was the highest, which also suggests that the concentrations of this heavy metal are greatly affected by human activity. $\mathrm{Hg}$ accumulation in heavily polluted areas was mostly distributed in residential areas, where motorized vehicles are common. Therefore, it can be inferred that the sources of $\mathrm{Hg}$ pollution mainly come from automobile exhaust, domestic waste, industrial waste gas, and others. The single factor index indicates that $\mathrm{Cu}, \mathrm{Cr}, \mathrm{Ni}$, and $\mathrm{As}$ pollution was light, and that there were no instances of medium or heavy pollution, showing that the concentrations of these elements are greatly affected by natural sources. In summary, $\mathrm{Zn}, \mathrm{Pb}, \mathrm{Cd}$, and $\mathrm{Hg}$ in the first principal component $(\mathrm{PC} 1)$ of the study area are greatly affected by anthropogenic sources, and $\mathrm{Cu}, \mathrm{Cr}, \mathrm{Ni}$, and $\mathrm{As}$ in the second principal component (PC2) are greatly affected by natural sources.

\section{Conclusions}

In this research, 156 soil samples were acquired from a typical landform in the lower Yellow River Basin to analyze heavy metal concentrations. We measured reight element contents $(\mathrm{Hg}, \mathrm{Zn}, \mathrm{Ni}, \mathrm{Cr}, \mathrm{Cd}, \mathrm{Cu}, \mathrm{As}$ and $\mathrm{Pb}$ ) and used the background value of the fluvoaquic soil in Henan Province to compare, after which SPSS 20.0 and ArcGIS 10.2 were used to characterize the spatial variation of the Nemerow pollution indexes. Then we discussed the pollution status and spatial distribution characteristics. And we also evaluated the potential ecological risk of soil in the low-lying land. Furthermore, according to correlation analysis and principal component analysis, we identified the source of soil heavy metals in the study area. Based on the background value of soil heavy metals to compare, the overall exceeding rate was not high. Only $\mathrm{Cd}$ exceeded the average pollution content, whereas $\mathrm{Hg}$, As, $\mathrm{Cu}, \mathrm{Cr}, \mathrm{Ni}, \mathrm{Pb}$, and $\mathrm{Zn}$ did not surpass the background value.

The optimal interpolation models of eight heavy metals in the study area are: $\mathrm{t} \mathrm{Cu}$ is the DK of constant, $\mathrm{Cr}$ is the DK of order 2, $\mathrm{Ni}$ is RBF of IS, $\mathrm{Zn}$ is the GPI of order $4, \mathrm{Cd}$ is the UK of order $1, \mathrm{As}$ is the RBF of IS, $\mathrm{Hg}$ is the UK of order $1, \mathrm{~Pb}$ is RBF of IS. The eight elements in the low-lying land exhibited higher values in the west, with lower values in the east; all heavy metals exhibited high-value zones, indicating that the prevalence of human activities in the highly polluted areas has a substantial affect. $\mathrm{Cr}, \mathrm{Ni}$, and As may result from point source pollution in the low-lying land. The comprehensive assessment of soil heavy metal pollution indicated that the total pollution ratio was $80.13 \%$, showing that much of the study area is slightly polluted. The heavily polluted areas in the study area mainly coincided with industrial zones and densely populated areas, where motorized vehicles and other human activities are relatively prevalent. Only $\mathrm{Cd}$ had reached a moderate risk level based on the potential ecological risk assessment in the low-lying land, whereas the other seven elements pose a low risk. A comprehensive potential ecological risk assessment also demonstrated that there is an overall low risk linked to heavy metals, with $\mathrm{Cd}$ being the main risk factor in the area. Moreover, although there was no significant correlation between $\mathrm{As}, \mathrm{Hg}$, and $\mathrm{Cd}$, other heavy metals exhibited a significant or very significant positive correlation. $\mathrm{Hg}$, $\mathrm{Cd}, \mathrm{Zn}$ and $\mathrm{Pb}$ were greatly affected by anthropogenic sources, and $\mathrm{Ni}, \mathrm{Cu}, \mathrm{Cr}$, and As were greatly affected by natural sources.

\section{Acknowledgements}

This research was funded by the National Natural Science Foundation of China (grant number 41601175, 41807066), the key scientific research project of Henan province (grant number 16A610001), the 2018 Young Backbone Teachers Foundation from Henan Province, (grant number 2018GGJS019,) the Program for Innovative Research Talent in University of Henan Province, (grant number 20HASTIT017), Key R\&D and extension projects in Henan Province in 2019 (agriculture and social development field), (grant number 192102310002), the Innovation Team Cultivation Project of The First-class Discipline in Henan University, (grant number 2018YLTD16), Philosophy and Social Sciences Planning Project of Henan Province, (grant number 2020BJJ020).

\section{Conflict of Interest}

The authors declare no conflict of interest. 


\section{References}

1. 1. POGGIO L., VRS ${ }^{\circ}$ CAJ B., HEPPERLE E., SCHULINA R., MARSAN F. A. Introducing a method of human health risk evaluation for planning and soil quality management of heavy metal-polluted soils - An example from Grugliasco (Italy). Landscape and Urban Planning 88, 64, 2008.

2. LI X.N., JIAO W.T., XIAO R.B., CHEN W.P., CHANG A.C. Soil pollution and site remediation policies in China: Areview. Environmental Reviews, 23 (3), 263, 2015.

3. TUME P., GONZÁLEZ E., KING R. W., CUITIÑO L., ROCA N., BECH J. Distinguishing between natural and anthropogenic sources for potentially toxic elements in urban soils of Talcahuano, Chile. Journal of Soils and Sediments, 18 (6), 2335, 2018.

4. OBIORA S.C., CHUKWU A., TOTEU S.F., DAVIES T.C. Assessment of Heavy Metal Contamination in Soils Around Lead $(\mathrm{Pb})$-Zinc ( $\mathrm{Zn})$ Mining Areas in Enyigba, Southeastern Nigeria. Journal of the Geological Society of India, 87, 453, 2016.

5. YADAV I.C., DEVI N.L., SINGH V.K., LI J., ZHANG G. Spatial distribution, source analysis, and health risk assessment of heavy metals contamination in house dust and surface soil from four major cities of Nepal. Chemosphere, 218, 1100, 2019.

6. SINGH O.V., LABANA S., PANDEY G., BUDHIRAJA R., JAIN R.K. Phytoremediation: an overview of metallic ion decontamination from soil. Applied Microbiology and Biotechnology, 61 (5-6), 405, 2003.

7. TANG J., ZHANG J., REN L., ZHOU Y., GAO J., LUO L., YANG Y., PENG Q., HUANG H., CHEN A Diagnosis of soil contamination using microbiological indices: A review on heavy metal pollution. Journal of Environmental Management, 242, 121, 2019.

8. COEN N., MOTHERSILL C., KADHIM M., WRIGHT E. Heavy metals of relevance to human health induce genomic instability. Journal of Pathology, 195, 293, 2001.

9. ARORA K., SHARMA S., MONTI A. Bio - remediation of $\mathrm{Pb}$ and $\mathrm{Cd}$ polluted soils byswitchgrass: A case study in India. International Journal of Phytoremediation, 18 (7), 704, 2016.

10. ZHOU K.S. Assessing Heavy Metal Pollution in Surface Sediments of China's Shaying River. Polish Journal of Environmental Studies, 28 (6), 4495, 2019.

11. ISLAM S., AHMED K., MASUNAGA S. Potential ecological risk of hazardous elements in different landuse urban soils of Bangladesh. Science of the Total Environment, 512-513, 94, 2015.

12. SRINIVASA G.S., RAMAKRISHNA R.M., GOVIL P.K. Assessment of heavy metal contamination in soils at Jajmau (Kanpur) and Unnao industrial areas of the Ganga plain,Uttar Pradesh, India. Journal of Hazardous Materials, 174, 113, 2010.

13. GAO X.Y., TANG Z.Y., LI J.H., WANG L. Current Situation of Soil Environmental Pollution and Countermeasures of Prevention and Control in China. Jiangsu Environmental Science and Technology, 19 (2), 52, 2006 [In Chinese].

14. ZHANG P.Y., YANG D., ZHANG Y., LI Y.Y., LIU Y., CEN Y.F, ZHANG W., GENG W.L., RONG T.Q., LIU Y., SHAO J.W. Re-examining the drive forces of China's industrial wastewater pollution based on GWR model at provincial level. Journal of Cleaner Production, 262, 121309, 2020.
15. MAAS S., SCHEIFLER R., BENSLAMA M., CRINI N., LUCOT E., BRAHMIA Z., BENYACOUB S., GIRAUDOUX P. Spatial distribution of heavy metal concentrations in urban, suburban and agricultural soils in a Mediterranean city of Algeria. Environmental Pollution, 158, 294, 2010.

16. BILGIN A., KONANC M.U. Evaluation of surface water quality and heavy metal pollution of Coruh River Basin (Turkey) by multivariate statistical methods. Environmental Earth Sciences, 75, 1029, 2016.

17. SUNGUR A., SOYLAK M., YILMAZ E., YILMAZ S., OZCAN H. Characterization of heavy metal fractions in agricultural soils by sequential extraction procedure: the relationship between soil properties and heavy metal fractions. Soil Sediment Contamination, 24 (1), 1, 2015.

18. WILCKE W. Small-scale variability of metal concentrations in soil leachates. Soil Science Society of America Journal, 64 (1), 138, 2000.

19. HAN Z.X., WAN D., TIAN H.X., HE W.X., WANG Z.Q., LIU Q. Pollution Assessment of Heavy Metals in Soils and Plants around a Molybdenum Mine in Central China. Polish Journal of Environmental Studies, 28 (1), 123, 2019.

20. ZHOU J., FENG K., LI Y.J., ZHOU Y. Factorial Kriging analysis and sources of heavy metals in soils of different land-use types in the Yangtze River Delta of Eastern China. Environmental Science and Pollution Research, 23, 14957, 2016.

21. YANG Q.Q., LI Z.Y., LU X.N., DUAN Q.N., HUANG L., BI J. A review of soil heavy metal pollution from industrial and agricultural regions in China: Pollution and risk assessment. Science of the Total Environment, 642, 690, 2018.

22. PETER A.E., NAGENDRA S.M.S., NAMBI I.M. Comprehensive analysis of inhalable toxic particulate emissions from an old municipal solid waste dumpsite and neighborhood health risks. Atmospheric Pollution Research, 9 (6), 1021, 2018.

23. SHI S.B., WANG X.D., YE Z.Q., CHEN W.B., LI T., CHEN J.H., LI J.W. Correction to: Effect of the combined application of fungal residue and chemical fertilizers on the mineralization of soil organic carbon in paddy fields. Environmental Science and Pollution Research, 26, 23305, 2019.

24. MALLARINO A.P. Spatial variability patterns of phosphorus and potassiumin no-tilled soil sfor two sampling scales. Soil Science Society of America Journal, 60 (5), 1473, 1996.

25. WANG M.S., HAN Q., GUI C.L., CAO J.L., LIU Y.P., HE X.D., HE Y.C. Differences in the risk assessment of soil heavy metals between newly built and original parks in Jiaozuo, Henan Province, China. Science of the Total Environment, 676, 1, 2019.

26. SUN Z.H., XIE X.D., WANG P., HU Y.N., CHENG H.F. Heavy metal pollution caused by small-scale metal ore mining activities: A case study from a polymetallic mine in South China. Science of the Total Environment, 639, 217, 2018.

27. LI K.J., GU Y.S., LI M.Z., ZHAO L. Spatial analysis, source identification and risk assessment of heavy metals in a coal mining area in Henan, Central China. International Biodeterioration Biodegradation, 128, 148, 2018.

28. WANG Z.X., PANG Z.H., GUO Q.W., CHEN J.Y., XU Z.C.,CHEN J.Q., SUN G.Q., HU X.B., LUO Q.J., HUANG R.X., LIN F.M. Introducing a land-use-based spatial analysis method for humanhealth risk evaluation of soil 
heavy metals. Environmental Earth Sciences, 70, 3225, 2013.

29. LIANG J., FENG C.T., ZENG G.M., GAO X., ZHONG M.Z., LI X.D., LI X., HE X.Y., FANG Y.L. Spatial distribution and source identification of heavy metals in surface soils in a typical coal mine city, Lianyuan, China. Environmental Pollution, 225, 681, 2017.

30. LU A.X., WANG J.H., QIN X.Y., WANG K.Y., WANG P., ZHANG S.Z. Multivariate and geostatistical analyses of the spatial distribution and origin of heavy metals in the agricultural soils in Shunyi, Beijing, China. Science of the Total Environment, 425, 66, 2012.

31. FU S., WEI C.Y. Multivariate and spatial analysis of heavy metal sources and vari-ations in a large old antimony mine, China. Journal of Soils and Sediments, 13, 106, 2012.

32. NAKAJIMA T., UMEYAMA M. Novel Solution for Low-Lying Land Areas Safe from Natural Hazards Toward Reconstruction of Lost Coastal Areas in Northeast Japan. Journal of Marine Science and Engineering, 3, 520, 2015.

33. HEMAKUMARA G., RUSLAN R. Geo-statistical modeling to evaluate the socio-economic impacts of households in the context of low-lying areas conversion in Colombo metropolitan region-Sri Lanka. AIP, 1643 (1), 438, 2015.

34. UNLAND N.P., TAYLOR H.L., BOLTON B.R., CARTWRIGHT I. Assessing the hydrogeochemical impact and distribution of acid sulphate soils, Heart Morass, West Gippsland, Victoria. Applied Geochemistry, 27, 2001, 2012.

35. HAN J.H., DU F.Y., LI W.P., GAO J.T., WANG X.Y., BAO J.Q., FAN A.P. Risk Assessment of Heavy Metals in Soils of the Yellow River Wetland (Xiaobai River Area). Jiangsu Agricultural Sciences, 45 (7), 239, 2017 [In Chinese].

36. JING W.L., YAO L., ZHAO X.D., ZHANG P.Y., LIU Y.X.Y., XIA X.L., SONG J., YANG J., LI Y., ZHOU C.H. Understanding Terrestrial Water Storage Declining Trends in the Yellow River Basin. Journal of Geophysical Research: Atmospheres, 124 (23), 12963, 2019.

37. LI P., E C.Y., WU C.Y., ZHANG J., LU S.C., YAN, W.T. A Study on Aeolian Parent Material Chronology in Source Region oh Yellow River. Bulletin of Soil and Water Conservation, 38 (5), 115, 2018 [In Chinese].

38. ZHANG H.W., ZHANG G.Z., ZHANG K.J., XIE X.T., WEI X.Y., WEI A.S., JIANG P. Analysis and Evaluation on Heavy Metal Contaminated Soilsin Vegetable Greenhouses of Irrigation Area of LanzhouSection of the Yellow River, China. Chinese Journal of Soil Science, $\mathbf{4 3}$ (6), 1493, 2012 [In Chinese].

39. MIAO X.Y., HAO Y.P., YANG L. J., YE S.Y., CHEN W.H., WANG T., CHEN H.F., HUANG B.J. Spatial Distrbution of Heavy Mentals in The Surface Soil of Yellow River Delta and Influence Factors. Marine Geology and Quaternary Geology, 36 (1), 57, 2016[In Chinese].

40. ZHANG P.Y., QIN M.Z., YAN J.H., YANG L., LI J., SUN C., CHEN L. Spatial variation of soil heavy metals in the beach of Lower Yellow River: A case study in Kaifeng Section. Geographical Research, 32 (3), 421, 2013 [In Chinese].

41. SANDRONI V., SMITH, C.M. M., DONOVAN A. Microwave digestion of sediment, soils and urban particulate matter for trace metal analysis. Talanta, 60 (4), 715, 2003.

42. ZHANG P.Y., YANG D., QIN M.Z., JING W.L. Spatial heterogeneity analysis and driving forces exploring of built-up land development intensity in Chinese prefecture- level cities and implications for future urban land intensive use. Land Use Policy, 99, 104958, 2020

43. ZHANG P.Y., QIN C.Z., HONG X., KANG G.H., QIN M.Z., YANG D., LI Y.Y., HE J.J., DICK R.P. Risk assessment and source analysis of soil heavy metal pollution from lower reaches of Yellow River irrigation in China. Science of the Total Environment, 633, 1136, 2018.

44. MORTON B.O., HERNANDEZ-ULVAREZ E., CONZALEZ H.G. Assessment of heavy metal pollution in urban top soils from the metropolitan area of Mexico City. Journal of Geochemical Exploration, 101 (3), 218, 2009.

45. NEMEROW N.L. Stream, Lake, Estuary, and Ocean Pollution, $2^{\text {nd }}$ ed. Van Nostrand Reinhold, New York, USA, 1991.

46. YI Y.J., YANG Z.F., ZHANG S.H. Ecological risk assessment of heavy metals in sediment and human health risk assessment of heavy metals in fishes in the middle and lower reaches of the Yangtze River basin. Environmental Pollution, 159 (10), 2575, 2011.

47. HANESCH M., SCHOLGER R. Mapping of heavy metal loadings in soils by means of magnetic susceptibility measurements. Environmental geology, 42 (8), 857, 2002.

48. ZHU W., BIAN B., LI L. Heavy metal contamination of road-deposited sediments in a medium size city of China. Environmental Monitoring and Assessment, 147, 171, 2008.

49. FATOBA P.O., OGUNKUNLE C.O., FOLARIN O.O., OLADELE F.A. Heavy metal pollution and ecological geochemistry of soil impacted by activities of oil industry in the Niger Delta, Nigeria. Environmental Earth Sciences, 75, 297, 2016.

50. HAKANSON L. An ecological risk index for aquatic pollution control: A sedimentological approach. Water Research, 14 (8), 975, 1980.

51. LUO T., DING T., SUN J., ZHOU W., ZHUO F. Pollution characteristics and assessmento heavy metals in wetland soil in the area of northern Jiangsu Province. Environmental Chemistry, 37, 984, 2018.

52. OGUNKUNLE C.O., FATOBA P.O. Contamination and spatial distribution of heavymetals in topsoil surrounding a mega cement factory. Atmospheric Pollution Research, 5 (2), 270, 2014.

53. FEI J.C., MIN X.B., WANG Z.X., PANG Z.H., LIANG Y.J., KE Y. Health and ecological risk assessment of heavy metals pollution in an antimony mining region: a case study from South China. Environmental Science and Pollution Research, 24 (35), 27573, 2017.

54. BURGES A., EPELDE L., GARBISU C. Impact of repeated single-metal and multi-metal pollution events on soil quality. Chemosphere, 120, 8, 2015.

55. FACCHINELLI A., SACCHI E., MALLEN L. Multivariate statistical and GIS-based approach to identify heavy metal sources in soils. Environmental Pollution, 114 (3), 313, 2001.

56. WILDING L. In Spatial variability: its documentation, accommodation and implication to soil surveys. Soil spatial variability, Workshop, 1985.

57. QIAO M., CAI C., HUANG Y. Z., LIU Y.X., LIN A.J. ZHENG Y.M. Characterization of soil heavy metal contamination and potential health risk in metropolitan region of northern China. Environmental Monitoring and Assessment, 172, 353, 2011.

58. GRAY C.W., MCLAREN R.G., ROBERTS, A.H.C. The effect of long-term phosphatic fertiliser applications on the amounts and forms of cadmium in soils under pasture in New Zealand. Nutrient Cycling in Agroecosystems, 54, 267, 1999. 